\title{
High Efficiency Covalent Radiolabeling of the Human Androgen Receptor Studies in Cultured Fibroblasts using Dihydrotestosterone 17 $\beta$-Bromoacetate
}

\author{
William J. Kovacs and Maxine K. Turney \\ Department of Medicine, Vanderbilt University School of Medicine, Nashville, Tennessee 37232
}

\begin{abstract}
Analysis of mutations affecting the androgen receptor protein in human cells has been limited because of the low abundance and lability of these proteins in target tissues. All methods used to date have been based on the noncovalent interaction of radiolabeled androgens with the receptor's ligand binding site. We report here synthesis and use of the electrophilic affinity label dihydrotestosterone $17 \beta$-bromoacetate. This ligand, prepared as a radioactive compound of high specific activity, rapidly and covalently binds to a protein of 58,000 daltons in cytosol from normal genital skin fibroblasts. This protein is a high affinity, saturable specific binding site for the ligand and was not detectable in cultured cells from a subject with androgen resistance or in receptor-negative nongenital fibroblasts. The efficiency of incorporation of the covalent radiolabel into the $58-\mathbf{k D}$ protein is greater than $80 \%$ based on estimates of receptor content using noncovalent ligands in intact cell assays. These studies demonstrate that dihydrotestosterone $17 \beta$-bromoacetate is useful for high efficiency covalent labeling of the human androgen receptor in crude cytosolic extracts from cultured cells.
\end{abstract}

\section{Introduction}

The human syndromes of androgen resistance are a class of apparent single gene mutations that result in impairment of the action of androgenic hormones on their target tissues (1). These disorders are thought to be due in most instances to defects in the intracellular receptor protein that binds these hormones. Such receptors are present in only trace amounts even in classic androgen target tissues, they are extremely labile under cell-free conditions, and they bind their ligands noncovalently. Despite these limitations, it has been possible to use cultured human genital skin fibroblasts as a source of the protein for analysis by a variety of methods based on the noncovalent binding of radiolabeled androgens $(2,3)$. As a consequence of such studies several classes of molecular defects in the androgen receptor have been described (1-3). These include subjects whose cells contain no detectable androgen binding activity ("receptor-negative") as well as those with diminished amounts of apparently normal receptor or subtle qualitative defects of the androgen receptor such as thermolability (4), instability on sucrose density gradients (5),

\footnotetext{
Address reprint requests to Dr. Kovacs.

Received for publication 18 May 1987 and in revised form $27 \mathrm{Au}$ gust 1987.
}

J. Clin. Invest.

(c) The American Society for Clinical Investigation, Inc. 0021-9738/88/02/0342/07 \$2.00

Volume 81, February 1988, 342-348 and ligand specificity alterations (6). Finally, there exist subjects with clear genetic, clinical, and endocrinologic evidence for androgen resistance whose cultured cells demonstrate no detectable quantitative or qualitative abnormality of the androgen receptor. Analysis in vitro of all the subclasses of androgen resistance with detectable androgen binding would be greatly facilitated by a radiolabel covalently attached to the receptor's steroid binding site. For this and other reasons a number of laboratories have sought to develop methods for photoaffinity labeling androgen receptors (7-12). The results have been uniformly disappointing either because of the very low efficiency of covalently labeling, because of extensive purification of receptors necessary prior to introduction of the affinity label, or because of lability of the receptor protein itself under conditions of photolysis. Recently Chang et al. (7, 8, 13, 14) have reported evidence that the electrophilic affinity label $17 \beta$-bromoacetyl oxy-5 $\alpha$ androstane-3-one (dihydrotestosterone $17 \beta$-bromoacetate) ${ }^{1}$ originally synthesized by Le Gaillard and Dautreavaux (15) and tested by Mainwaring (16), binds covalently to purified androgen receptors from rat prostate, from a transplantable prostatic tumor and from bovine seminal vesicle.

We report here that this compound binds covalently with high affinity to a saturable 58,000-D protein from human genital skin fibroblasts. The binding site is specific for androgenic hormones. This $58,000-\mathrm{D}$ binding protein is not detectable in cytosolic extracts of androgen receptor-negative cells from a patient with androgen resistance or in cytosol of nongenital fibroblasts from normal individuals.

\section{Methods}

Cell culture. Genital fibroblast stains were established from explants of skin obtained from normal circumcisions, or, in the case of androgen resistance subjects, from biopsies. Nongenital fibroblast strains used were established from explants of normal thymic tissue obtained at open heart surgery. Explants were placed in $25 \mathrm{~cm}^{2}$ flasks and bathed in $20 \%$ FCS in minimum essential medium. When fibroblasts had grown out from the tissue fragment the cells were passaged by trypsinization and sequential reseeding in new flasks. The cells were then grown in minimum essential medium supplemented with $10 \%$ FCS and were used before passage number 20. Stocks of strains were stored frozen in liquid nitrogen at low transfer numbers. For experiments, the cells were grown in medium with $10 \%$ FCS. $24 \mathrm{~h}$ before the experiment the medium was aspirated, the plates washed with Dulbecco's PBS and medium without serum with $500 \mu \mathrm{g} / \mathrm{ml}$ sterile BSA was added.

Monolayer androgen binding assays. Intact cell binding assays were carried out by the method of Griffin et al. (17). Cells for monolayer binding assays were grown in $6-\mathrm{cm}$ diam wells. On the day of the

1. Abbreviations used in this paper: dihydrotestosterone $17 \beta$-bromoacetate, $17 \beta$-bromoacetyl oxy- 5 androstane-3-one; RBA, relative binding affinity; TEGSH, $10 \mathrm{mM}$ Tris, pH 7.4, with $1 \mathrm{mM}$ EDTA, $10 \%$ glycerol, $12 \mathrm{mM}$ monothioglycerol. 
experiment the wells were rinsed with $2 \mathrm{ml}$ of medium without serum and incubated at $37^{\circ} \mathrm{C}$ for $60 \mathrm{~min}$ with medium containing various concentrations $(0.05-2.5 \mathrm{nM})$ of the synthetic androgen [ $17 \alpha$ methyl ${ }^{3} \mathrm{H}$ ]methyltrienolone (specific activity $=90 \mathrm{Ci} / \mathrm{mmol}$ ). Parallel wells contained a 500 -fold excess of nonradioactive methyltrienolone. The monolayers were washed five times with $50 \mathrm{mM}$ Tris $\mathrm{pH} 7.4$ with $0.9 \%$ $\mathrm{NaCl}$ (Tris-saline) and $2 \mathrm{~g} /$ liter fraction $\mathrm{V}$ BSA. The cells were washed twice more with Tris-saline and harvested by trypsinization. The cells were pelleted by centrifugation, washed twice more with Tris-saline and the pellets suspended in $1 \mathrm{ml}$ of water. The samples were sonicated and $0.5 \mathrm{ml}$ taken for quantitation of bound radioactivity. An aliquot $(0.1 \mathrm{ml})$ of the sonicate was used for measurement of protein concentration by the method of Lowry (18).

Dihydrotestosterone 17 1 -bromoacetate synthesis. Nonradioactive dihydrotestosterone $17 \beta$-bromoacetate was synthesized by the method described by Le Gaillard and Dautrevaux (15). $80 \mathrm{mg}$ of dihydrotestosterone ( $5 \alpha$-androstane-3-one) and $35 \mathrm{mg}$ of bromoacetic acid were dissolved in $2 \mathrm{ml}$ of tetrahydrofuran. The samples was chilled to $-20^{\circ} \mathrm{C}$ and $55 \mathrm{mg}$ of dicyclohexylcarbodiimide and $18 \mu \mathrm{l}$ of pyridine were added. The sample was incubated at $4^{\circ} \mathrm{C}$ for $4.5 \mathrm{~h}$. Progress of the reaction was monitored on mini thin-layer chromatography plates (10 $\mathrm{cm}$ ) spotted with reaction mixture and developed in 9:1 parts chloroform/acetone. The reaction mixture was filtered through glass wool to remove precipitated dicyclohexylurea, and dried under a nitrogen stream. The residue was dissolved in $2 \mathrm{ml}$ of chloroform and chromatographed through a silica gel column equilibrated in chloroform. The eluted peak of dihydrotestosterone $17 \beta$-bromoacetate was dried under a nitrogen stream. Approximately $40 \mathrm{mg}$ of pure product was obtained. The nonradioactive compound was analyzed by nuclear magnetic resonance spectroscopy.

Radioactive dihydrotestosterone $17 \beta$-bromoacetate was synthesized by the method described by Chang et al. (13). $1 \mathrm{nmol}(180 \mu \mathrm{l}$ of a stock of $5.56 \mu \mathrm{M})$ of $\left[1,2,4,5,6,7-{ }^{3} \mathrm{H}\right]$ dihydrotestosterone $(180 \mathrm{Ci} /$ mmol) was transferred to a test tube and the solvent removed by evaporation under a nitrogen stream. $50 \mu \mathrm{l}$ of bromoacetyl bromide $(2.31 \mu \mathrm{g} / \mu \mathrm{l}$ in toluene) and $50 \mu \mathrm{l}$ of diisopropylethylamine $(1.44 \mu \mathrm{g} / \mu \mathrm{l}$ in toluene) were added and the reaction carried out at room temperature. After $4.5 \mathrm{~h}$ the solvent was evaporated and $50 \mu \mathrm{l}$ of each stock was again added. After $18 \mathrm{~h}$ the solvent was evaporated, the residue dissolved in hexane/ether (6:4) and applied to a silica gel column equilibrated in the same system. The dihydrotestosterone $17 \beta$-bromoacetate eluted in the first three fractions from the column. Eluted radiolabel was further purified on thin-layer chromatography plates developed in chloroform/acetone (9:1). The resulting compound was $95 \%$ pure as determined by thin-layer chromatography with purified dihydrotestosterone $17 \beta$-bromoacetate as an internal marker.

Human fibroblast cytosol preparation. Cultured human fibroblasts were withdrawn from serum for $24 \mathrm{~h}$ before experiments. On the day of the experiment the monolayers (20-30 plates $10 \mathrm{~cm}$ in diameter) were washed three times with Tris-saline and harvested by scraping. The cells were washed again in Tris saline, and once in TESH buffer (10 mM Tris, pH 7.4, 1 mM EDTA, 12 mM monothioglycerol) with 10 $\mathrm{mM} \mathrm{Na}_{2} \mathrm{MoO}_{4}$ and $10 \mu \mathrm{M}$ leupeptin. The cell pellet was homogenized in a glass Dounce homogenizer in an equal volume of TEGSH $(10 \mathrm{mM}$ Tris pH 7.4, with $1 \mathrm{mM}$ EDTA, $10 \%$ glycerol, and $12 \mathrm{mM}$ monothioglycerol) with $10 \mathrm{mM} \mathrm{Na}_{2} \mathrm{MoO}_{4}$ and $10 \mu \mathrm{M}$ leupeptin. The homogenate was centrifuged at $100,000 \mathrm{~g}$ for $60 \mathrm{~min}$ at $4^{\circ} \mathrm{C}$. The supernatant is referred to as cytosol.

$\left[{ }^{3} \mathrm{H}\right]$ Dihydrotestosterone competition assay. Normal human genital skin fibroblast cytosol was incubated in $200-\mu$ l aliquots with $3 \mathrm{nM}$ $\left[{ }^{3} \mathrm{H}\right]$ dihydrotestosterone $(180 \mathrm{Ci} / \mathrm{mmol})$ in the presence of increasing (0-300 $\mathrm{nM})$ concentrations of nonradioactive dihydrotestosterone or dihydrotestosterone $17 \beta$-bromoacetate. After an overnight incubation at $0^{\circ} \mathrm{C}$ bound hormone was separated from free hormone by the hydroxylapatite method (19). Bound radioactivity was measured by liquid scintillation counting. Relative binding affinity of dihydrotestosterone $17 \beta$-bromoacetate was calculated from the amount of nonra- dioactive hormone required to displace $50 \%$ of the labeled dihydrotestosterone.

$\left[{ }^{3} \mathrm{H}\right]$ Dihydrotestosterone $17 \beta$-bromoacetate binding reaction. $\mathrm{Cy}-$ tosol from normal or mutant human genital skin fibroblasts or receptor negative nongenital fibroblasts was prepared as described. Aliquots of cytosol (1.5-2.0 ml) were added to tubes containing a 1-ml pellet of phosphocellulose (Whatman Ltd., Maidstone, Kent, England) washed and equilibrated in TEGSH and $\mathrm{Na}_{2} \mathrm{MoO}_{4}$. The slurry was incubated for $15 \mathrm{~min}$ at $0^{\circ} \mathrm{C}$, the phosphocellulose pelleted by centrifugation at $800 \mathrm{~g}$ for $5 \mathrm{~min}$ and the supernatant cytosol recovered. $0.5 \mathrm{ml}$ of TEGSH with $10 \mathrm{mM} \mathrm{Na}_{2} \mathrm{MoO}_{4}$ and $10 \mu \mathrm{M}$ leupeptin was used to wash the phosphocellulose pellet. This wash was added to the cytosol.

The phosphocellulose-treated cytosol was incubated for various times with various concentrations of $\left[{ }^{3} \mathrm{H}\right]$ dihydrotestosterone $17 \beta$ bromoacetate at $0^{\circ} \mathrm{C}$. The radiolabeled proteins were then applied to DEAE-cellulose columns (1-ml bed volume) equilibrated in TEGSH with $\mathrm{Na}_{2} \mathrm{MoO}_{4}$ and leupeptin. The columns were washed with 10 bed volumes of TEGSH with $\mathrm{Na}_{2} \mathrm{MoO}_{4}$ and the bound proteins eluted with $3 \mathrm{ml}$ of TEGSH-MoO ${ }_{4}$ with $0.2 \mathrm{M} \mathrm{NaCl}$. Noncovalently labeled androgen receptors in cytosol treated by the above methods are purified approximately two- to fourfold. The column eluates were dialyzed overnight in TESH. The next morning the proteins were precipitated with $10 \%$ trichloroacetic acid and washed with $2 \mathrm{ml}$ of $1: 1$ ether/acetone. The pellets were dissolved in $100 \mu \mathrm{l}$ of $8 \mathrm{M}$ urea and an equal volume of double concentrated SDS sample buffer (20) was added.

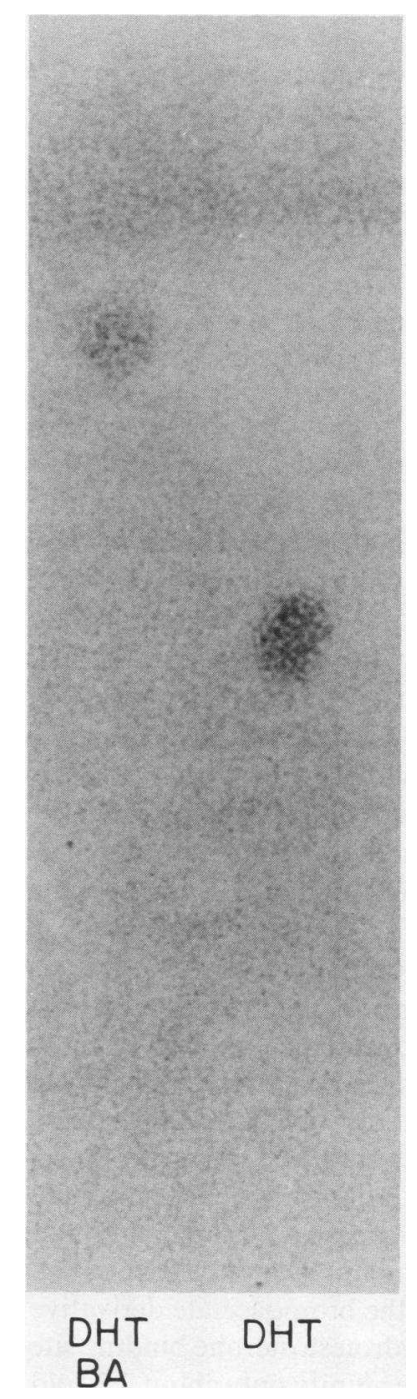

Figure 1. Thin-layer chromatography of synthesized dihydrotestosterone $17 \beta$-bromoacetate. Aliquots of stock solutions $(50 \mu \mathrm{g}$ total weight) of dihydrotestosterone (DHT) or dihydrotestosterone $17 \beta$-bromoacetate (DHT BA) dissolved in chloroform were spotted on silica gel thin layer chromatography plates and developed in a solvent system of 9:1 chloroform/ acetone. The steroids were visualized by spraying the plates with $10 \%$ phosphomolybdate in acetone and heating the plates for 10 min. 


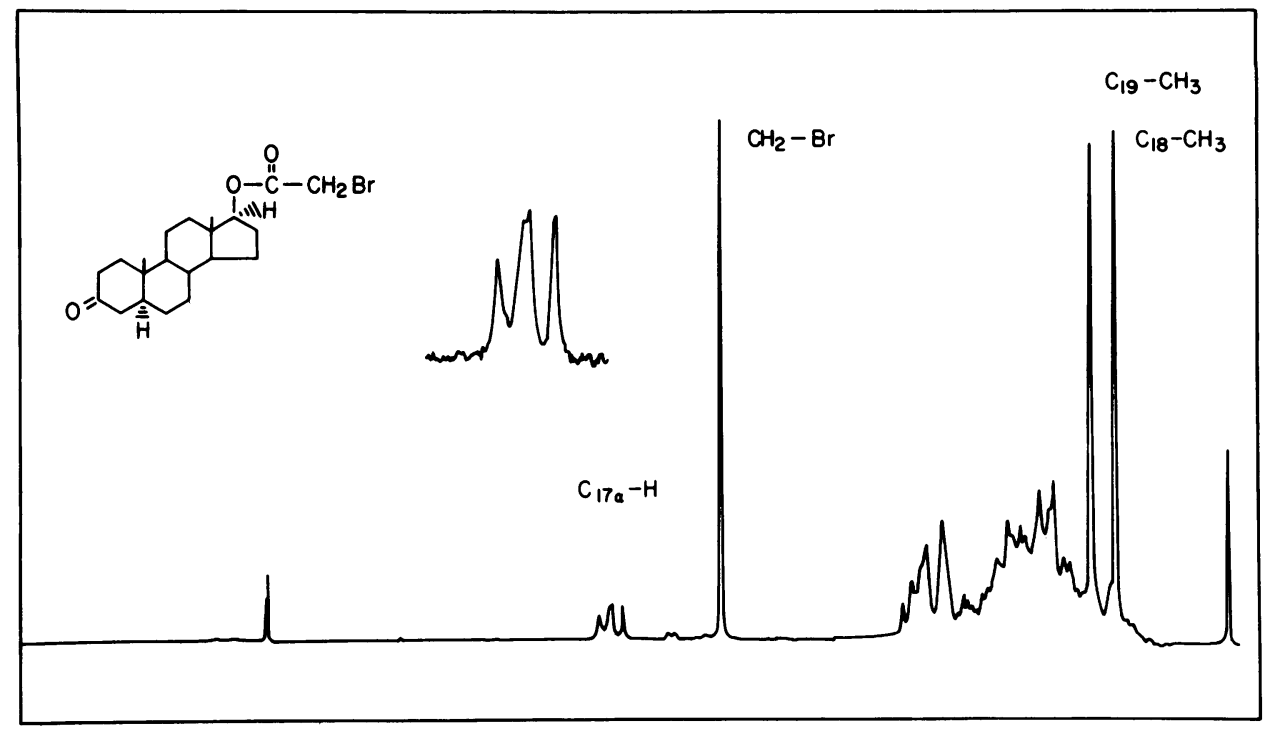

Figure 2. Proton magnetic resonance spectrum of dihydrotestosterone $17 \beta$-bromoacetate. $30 \mathrm{mg}$ of dihydrotestosterone $17 \beta$-bromoacetate in chloroform were analyzed by proton magnetic resonance with tetramethyl silane as a reference. The far downfield peak $(\delta=7.269)$ is due to a solvent proton. (Inset) Structural formula of dihydrotestosterone $17 \beta$-bromoacetate.
Samples were stored frozen in liquid nitrogen until analysis by denaturing PAGE.

SDS PAGE. Frozen samples were thawed, heated for $3 \mathrm{~min}$ at $100^{\circ} \mathrm{C}$, and aliquots analyzed by denaturing PAGE by the method of Laemmli (20). The concentration of acrylamide was 3\% in the stacking gel and $7.5 \%$ in the resolving gel. Gels were run at constant voltage (120 V) until samples entered the resolving gel; the voltage was then increased to $200 \mathrm{~V}$. Total running times averaged $4 \mathrm{~h}$. After electrophoresis gels were fixed overnight in 50\% methanol and $10 \%$ acetic acid. They were transferred the next morning to $5 \%$ methanol with $7 \%$ acetic acid for $1 \mathrm{~h}$ and rinsed twice in cold tap water. The gels were then soaked for $1 \mathrm{~h}$ in Enhance (New England Nuclear, Boston, MA) and 1 $\mathrm{h}$ in $2 \%$ glycerol. The gels were dried under a vacuum and exposed to Kodak XAR film for $48 \mathrm{~h}$ at $-70^{\circ} \mathrm{C}$ before developing.

\section{Results}

Synthesis of the nonradioactive dihydrotestosterone $17 \beta$-bromoacetate yielded $40 \mathrm{mg}$ of pure product. Thin-layer chromatography of the material revealed a rapidly migrating spot clearly distinct from authentic dihydrotestosterone in the solvent system used (Fig. 1). Proton magnetic resonance spectroscopy of the pure compound was consistent with the postulated structure (Fig. 2). The $\mathrm{C}_{18}$ methyl group produced a sharp singlet at $\delta=0.8440$; the $C_{19}$ methyl singlet appeared at $\delta$ $=1.0225$. The bromoacetate methylene singlet was at $\delta$ $=3.8251$ while the $\mathrm{C17} \alpha$-hydrogen produced a triplet with peaks at $\delta=4.5906,4.66$, and 4.767. This spectrum is identical to the published spectrum of the compound (13).

Analysis of the radioactive form of the synthesized compound (specific activity $=180 \mathrm{Ci} / \mathrm{mmol}$ ) by thin-layer chromatography showed $>95 \%$ of the radioactivity comigrating with authentic pure dihydrotestosterone $17 \beta$-bromoacetate.

The nonradioactive compound was first tested to determine whether it could interact with the androgen binding site of the human receptor, and to determine a binding affinity of the compound relative to authentic dihydrotestosterone (Fig. 3). Under equilibrium conditions the bromoacetate derivative competed for the high affinity dihydrotestosterone binding site in cytosol with an apparent relative affinity only about 2.3 -fold lower than dihydrotestosterone (relative binding affinity, $\mathrm{RBA}$, of dihydrotestosterone $=1 ; \mathrm{RBA}$ of dihydrotestosterone $17 \beta$-bromoacetate $=0.43$ ) .

$\left[1,2,4,5,6,7-{ }^{3} \mathrm{H}\right]$ Dihydrotestosterone $17 \beta$-bromoacetate labeled a single protein of $58 \mathrm{kD}$ from normal genital skin fibroblast cytosol (Fig. 4, lane 3). The radiolabel associated with this protein was resistant to denaturation with trichloroacetic acid, organic extraction with ether and acetone, and denaturation with $8 \mathrm{M}$ urea and SDS containing buffer under reducing conditions at $100^{\circ} \mathrm{C}$. Radioactive dihydrotestosterone binding is not resistant to these conditions, and no detectable radiolabeled protein band could be seen when authentic dihydrotestosterone was used as the radioligand (Fig. 4, lane 1). The time course of covalent incorporation of radioactive steroid into the $58-\mathrm{kD}$ protein was extremely rapid. After $10 \mathrm{~min}$ of incubation at $4^{\circ} \mathrm{C}$ with the radioactive ligand a clearly labeled 58-kD band was visible on SDS PAGE. By 30 min the intensity of the band was $>80 \%$ maximal. By $60 \mathrm{~min}$, incorporation of label

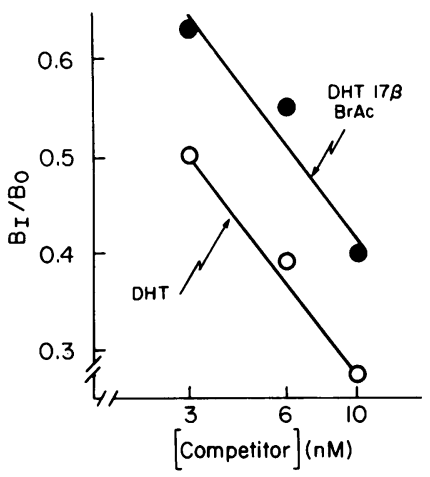

Figure 3. Competition of dihydrotestosterone and dihydrotestosterone $17 \beta$-bromoacetate for human androgen receptor binding site. Aliquots $(200 \mu \mathrm{l})$ of human fibroblast cytosol were incubated with $3 \mathrm{nM}$ $\left[{ }^{3} \mathrm{H}\right]$ dihydrotestosterone in the presence of increasing concentrations of nonradioactive dihydrotestosterone or dihydrotestosterone $17 \beta$-bromoacetate. After an overnight incubation at $0^{\circ} \mathrm{C}$ bound hormone was separated from free hormone by the hydroxylapatite method. The percentage of $\left[{ }^{3} \mathrm{H}\right]$ dihydrotestosterone bound is plotted as a function of the concentration of nonradioactive competitor (on a logarithmic scale) present in the assay. $50 \%$ of the radiolabel was displaced by 3 $\mathrm{nM}$ nonradioactive dihydrotestosterone and by $\sim 7 \mathrm{nM}$ dihydrotestosterone $17 \beta$-bromoacetate. Displacement data are shown only for the linear portion of the respective curves. 


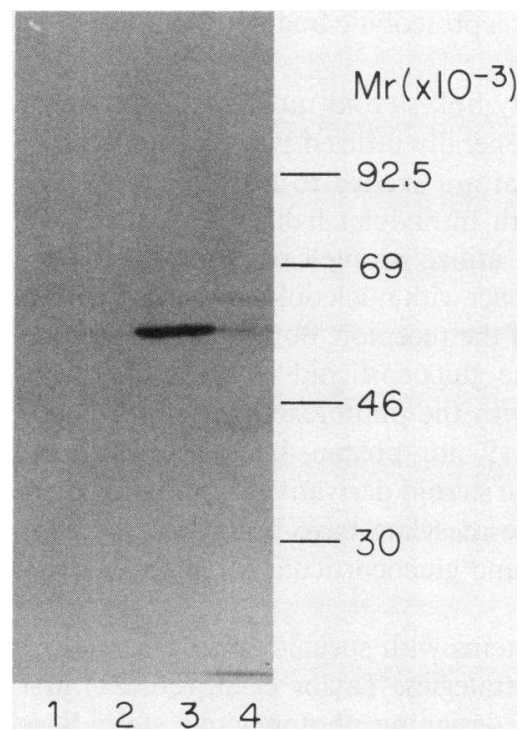

Figure 4. Covalent labeling of $58 \mathrm{kD}$ molecular weight fibroblast cytosolic protein by dihydrotestosterone $17 \beta$ bromoacetate. $\left[{ }^{3} \mathrm{H}\right] \mathrm{Di}$ hydrotestosterone $17 \beta$ bromoacetate was used to covalently label normal human genital skin fibroblast cytosolic proteins as described. The products were analyzed by denaturing polyacrylamide gel electrophoresis. (Lane 1) Control sample incubated with $5 \mathrm{nM}\left[{ }^{3} \mathrm{H}\right]$ dihydrotestosterone. (Lane 2) Control sample incubated with $5 \mathrm{nM}\left[{ }^{3} \mathrm{H}\right]$ dihydrotestosterone plus a 500-fold excess of nonradioactive dihydrotestosterone. (Lane 3) Sample covalently labeled with $5 \mathrm{nM}$ $\left[{ }^{3} \mathrm{H}\right]$ dihydrotestosterone $17 \beta$-bromoacetate. (Lane 4) Sample incubated with $5 \mathrm{nM}\left[{ }^{3} \mathrm{H}\right]$ dihydrotestosterone $17 \beta$-bromoacetate plus a 500 -fold excess of nonradioactive dihydrotestosterone $17 \beta$-bromoacetate. Molecular weight standards are marked at the left.

into three other faint bands was seen. These faint bands appeared at $\sim 62,000,44,000$, and $32,000 \mathrm{D}$. Elevation of reaction temperature to $25^{\circ} \mathrm{C}$ for $30 \mathrm{~min}$ after maximal labeling at $0^{\circ} \mathrm{C}$ did not result in increased incorporation into the 58-kD protein. Prior treatment of the cytosol with dimethylsuberimidate (to cross-link subunits) prevented all binding of the ligand (data not shown).

The $58-\mathrm{kD}$ protein is a saturable binding protein. In the presence of $2.5 \mu \mathrm{M}$ nonradioactive dihydrotestosterone $17 \beta$ bromoacetate the radiolabel was displaced (Fig. 4, lane 4). In the presence of excess nonradioactive ligand the 62,000 - and 44,000 -D bands were clearly visible, indicating that they represent nonsaturating interactions of the ligand with other proteins. While a Coomassie Blue-stained lane of the labeled cellular extract showed a vast number of protein bands (and a major species at molecular weight $=44,000$ ), there was no visible Coomassie stainable band in the vicinity of the radiolabel. Further evidence for the saturability of the $58-\mathrm{kD}$ protein's ligand binding site is shown in Figs. 5 and 6. Near-maximal band intensity is achieved by $30 \mathrm{~min}$ incubation with $5 \mathrm{nM}$ $\left[{ }^{3} \mathrm{H}\right]$ dihydrotestosterone $17 \beta$-bromoacetate. Half-maximal band intensity is achieved at $\sim 1.75 \mathrm{nM}$ concentration, consistent with the observed binding affinity relative to dihydrotestosterone shown above.

The specificity of $\left[{ }^{3} \mathrm{H}\right]$ dihydrotestosterone $17 \beta$-bromoacetate binding to the $58-\mathrm{kD}$ protein was evaluated in competition experiments using nonradioactive steroids. While preincubation with a 500 -fold excess of dihydrotestosterone $17 \beta$ bromoacetate could completely ( $>95 \%$ ) prevent binding of the radioligand, competition by noncovalently reacting ligands was less dramatic. Only dihydrotestosterone was capable of competing for the binding site with the ${ }^{3} \mathrm{H}$ affinity label. A 500 -fold excess of dihydrotestosterone was capable of diminishing the covalent binding of dihydrotestosterone $17 \beta$-bro-

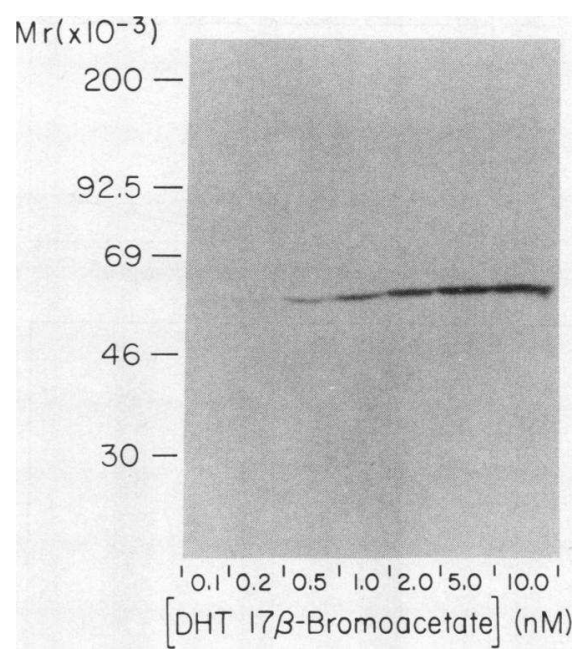

Figure 5. Saturation of $58-\mathrm{kD}$ binding protein by $\left[{ }^{3} \mathrm{H}\right]$ dihydrotestosterone $17 \beta$-bromoacetate. Denaturing SDS-PAGE of normal genital skin fibroblast cytosolic proteins covalently labeled with $\left[{ }^{3} \mathrm{H}\right]$ dihydrotestosterone $17 \beta$-bromoacetate. Samples in lanes $1-7$ were incubated with $0.1,0.2,0.5,1.0,2.0,5.0$, and $10.0 \mathrm{nM}$ concentrations of $\left[{ }^{3} \mathrm{H}\right]$ ligand, respectively, and processed as described.

moacetate to the $58-\mathrm{kD}$ protein by $23-36 \%$ in these experiments. Other steroids in similar quantities (testosterone, estradiol, triamcinolone acetonide) were not effective as competitors (data not shown).

While the 58-kD protein that binds dihydrotestosterone $17 \beta$-bromoacetate is easily detectable in normal genital skin fibroblasts, the functional protein appears to be absent from androgen receptor-negative cells (Fig. 7). Neither cells cultured from genital skin of a patient with clinical evidence of androgen resistance and no detectable androgen receptor by conventional monolayer binding assay nor nongenital fibroblasts with similar receptor-negative characteristics demonstrate the $58-\mathrm{kD}$ protein binding of the radioligand. Even when incubations were extended to $60 \mathrm{~min}$, radiolabel was incorporated in small amounts into the nonsaturable bands at 62,000 and $44,000 \mathrm{D}$ but only faint traces of radioactivity were detected at $58,000 \mathrm{D}$.

We have attempted to estimate the efficiency of covalent incorporation of dihydrotestosterone $17 \beta$-bromoacetate into the androgen receptor protein. Based on measurement of ra-

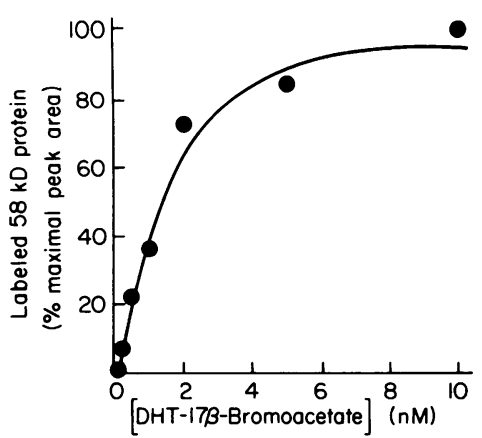

Figure 6. Saturation of 58-kD binding protein by $\left[{ }^{3} \mathrm{H}\right]$ dihydrotestosterone $17 \beta$-bromoacetate. Integrated peak areas of the labeled $58-\mathrm{kD}$ proteins shown in Fig. 5 were determined by scanning densitometry. Peak area (as percentage of maximal) is expressed as a function of radioligand concentration in the incubation mixtures. Molecular weight standards are marked at the left. 


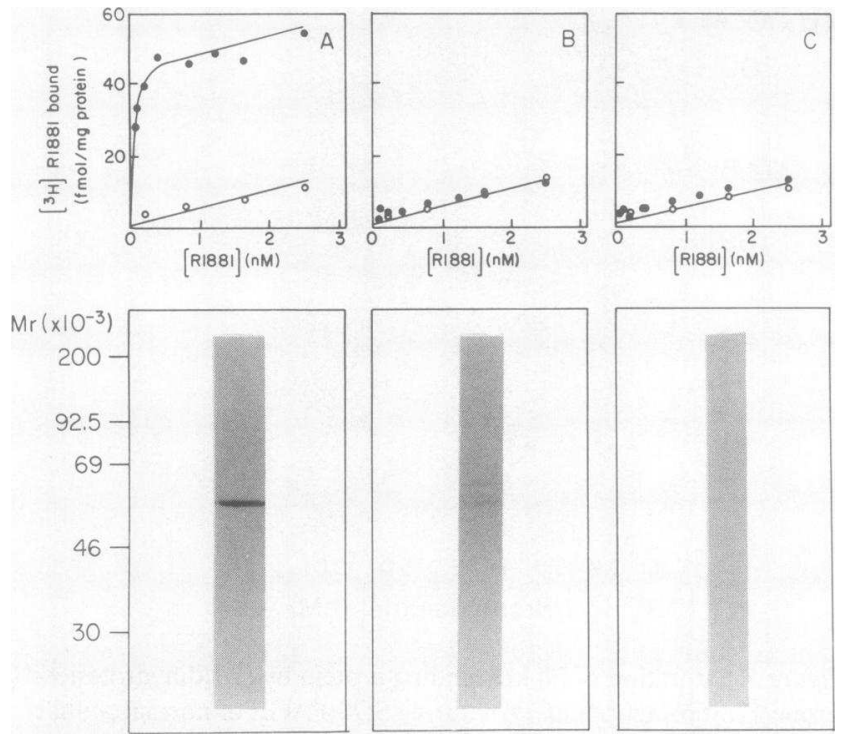

Figure 7. $\left[{ }^{3} \mathrm{H}\right]$ Dihydrotestosterone $17 \beta$-bromoacetate labeling of cytosolic proteins from control and androgen receptor-negative cells. $(A-C)$ Cultured fibroblasts from normal genital skin $(A)$, from genital skin of a subject with complete androgen resistance $(B)$, and from nongenital tissues from a subject with no evidence of androgen resistance $(C)$ were analyzed for androgen receptor content by the intact cell monolayer binding assay. Total $(\bullet)$ and nonspecific $(0)$ binding of $\left[{ }^{3} \mathrm{H}\right]$ methyltrienolone (in femtomoles steroid bound per milligram cellular protein) is plotted as a function of radioactive steroid concentrations. Lower panels: cytosolic proteins from these same cell lines were labeled with $\left[{ }^{3} \mathrm{H}\right]$ dihydrotestosterone $17 \beta$-bromoacetate, electrophoresed on denaturing polyacrylamide gels, and visualized by fluorography. $(A)$ Control genital fibroblasts; $(B)$ receptor-negative genital fibroblasts from a subject with androgen resistance; $(C)$ androgen-receptor negative cells from nongenital tissue. Total protein loaded onto gels was $490 \mu \mathrm{g}(A)$ and $360 \mu \mathrm{g}(B$ and $C)$. Molecular weight standards are marked at the left.

diolabel incorporation into the $58-\mathrm{kD}$ protein, and estimates of androgen receptor content of these human cells using standard assays with noncovalent ligands, the efficiency of covalent labeling appears to be $>80 \%$.

\section{Discussion}

These experiments demonstrate that dihydrotestosterone $17 \beta$ bromoacetate forms a covalent bond with the steroid binding site of the human androgen receptor in crude fibroblast cytosolic preparations. Nonradioactive dihydrotestosterone $17 \beta$ bromoacetate competes with relatively high affinity for the $\left[{ }^{3} \mathrm{H}\right]$ dihydrotestosterone binding protein in human fibroblast cytosol. Binding of the synthetic radioligand is rapid and specific for a 58,000-D protein in normal human genital skin fibroblast cytosol. This protein is a saturable high affinity receptor for the ligand and its binding site demonstrates androgenic specificity. The protein is not detectable in preparations of cytosol from androgen receptor-negative genital skin fibroblasts from a subject with androgen resistance or androgen receptor-negative fibroblasts from normal human thymus. These data strongly suggest this protein is a component (i.e., a steroid binding subunit or a proteolytic fragment) of the native human androgen receptor.

Attempts to covalently link steroid molecules to their respective receptors have generally utilized two types of probes: photoreactive steroids that are excited to form reactive moieties when irradiated with ultraviolet light and electrophilic steroid affinity labels that utilize strong leaving groups to generate intermediates that react with nucleophilic residues within the steroid binding site of the receptor. Both the progesterone receptor $(21,22)$ and the glucocorticoid receptor $(23)$ have been covalently linked with the photoreactive synthetic progestin 17 $\alpha$,21-dimethyl-19-nor-pregna-4,9diene-3,20-dione (R5020). The electrophilic steroid derivatives Tamoxifen aziridine and dexamethasone mesylate have been used to covalently label the estrogen and glucocorticoid receptors, respectively $(24,25)$.

Studies involving proteins with specific androgen binding sites have used similar strategies. Taylor et al. $(26,27)$ first showed the feasibility of designing photoreactive steroids as probes for androgen binding proteins. Several laboratories have attempted to exploit such a strategy for labeling androgen receptors using the synthetic, commercially available radioligand methyltrienolone (7-12). These reports are noteworthy for the necessity of prior purification of the receptor protein in order to detect "specific" (i.e., displaceable by excess nonradioactive ligand) binding and for the large amount of starting material necessary for the experiments. Estimated efficiency of the covalent linking of these receptor-ligand complexes ranged from 0.2 to a maximum of $6.8 \%$.

Because of these extreme limitations of photoaffinity labeling with methyltrienolone we have studied the electrophilic affinity label dihydrotestosterone $17 \beta$-bromoacetate. Using methods originally described for attempts to covalently label abundant secretory proteins (15), Mainwaring and Johnson (16) found difficulty in producing radioligand of sufficiently high specific activity with the bromoacetate moiety as the carrier of the radiolabel. The commercial availability of high specific activity radiolabeled dihydrotestosterone has now obviated those difficulties. Chang et al. (13) synthesized high specific activity $\left[{ }^{3} \mathrm{H}\right]$ dihydrotestosterone $17 \beta$-bromoacetate from $\left[1,2,4,5,6,7,16,17-{ }^{3} \mathrm{H}\right]$ dihydrotestosterone and used it to covalently label highly purified rat prostate cytosolic androgen receptors $(8,13,14)$, as well as purified androgen receptors from bovine seminal vesicle (7). We report here the first application of such methodology to human cells, and the crucial demonstration that the protein labeled by dihydrotestosterone $17 \beta$-bromoacetate is absent from receptor negative cell strains.

The protein specifically radiolabeled in human cells in our experiments had an average molecular mass of $58,000 \mathrm{D}$. Not surprisingly, a number of other molecular weights have been reported for putative androgen receptors linked with affinity labels. The apparent molecular weight of the rat prostate androgen receptor has been reported from photoaffinity labeling studies with methyltrienolone as $46,000-50,000 \mathrm{D}(7,8)$ as well as $86,000 \mathrm{D}(8,13)$. In bovine seminal vesicle a radiolabeled band of $60,000 \mathrm{D}$ was reported. Rowley et al. (14) found an apparent molecular mass of $117,000 \mathrm{D}$ for the Dunning R3327 prostate tumor. Using human foreskin, Gyorki et al. have published data showing broad bands of methyltrienolone binding centered around molecular masses of $\sim 85,000$ and $40,000 \mathrm{D}$ (12). In a single experiment using human genital skin 
fibroblasts these authors also found similar sized peaks of radioactivity. The nature of these differences in reported molecular weight is, of course, not known. Our findings could reflect labeling of an intact receptor subunit or could be the result of some uncontrolled proteolytic activity in fibroblast cytosol.

Two other groups of investigators have reported findings of relevance to this report. Risbridger et al. reported that normal genital skin fibroblasts contained two constitutively expressed proteins $(85,000$ and $45,000 \mathrm{D})$ that were absent from cells of subjects with complete testicular feminization (28). Rosenmann et al. (29) and Thompson et al. (30) reported a 56,000-D protein that appeared in genital skin fibroblasts but was absent from nongenital fibroblasts. Most recently, these investigators have made a preliminary report that this 56,000 -D protein can be photolabeled with methyltrienolone (31). The nature of all these protein products, and their relationship to the androgen receptor is not established.

Our data demonstrate that dihydrotestosterone $17 \beta$-bromoacetate is a highly effective affinity label for the human fibroblast androgen receptor. This will provide a tool for direct structural analysis on two-dimensional polyacrylamide gels of putatively mutant androgen receptors from subjects with "receptor-positive" androgen resistance. In addition, receptors with intact androgen binding sites but presumed qualitative abnormalities will be amenable to analysis by such technique. Finally, this affinity label should be a tool of considerable importance for detailed studies of the steroid binding site of the normal human androgen receptor and should facilitate purification of these trace and labile proteins.

\section{Acknowledgments}

Cell culture medium for these studies was supplied by the Vanderbilt University Diabetes Research and Training Center Core Laboratory. Proton magnetic resonance analysis of synthesized dihydrotestosterone $17 \beta$-bromoacetate was provided by the Organic Chemistry Core Laboratory of the Vanderbilt University Center for Reproductive Biology Research. Genital fibroblasts from the subject with androgen resistance were obtained from skin biopsy of a patient of Dr. Carl M. Herbert, Center for Fertility and Reproductive Research, Vanderbilt University. We wish to thank Ms. Shelia Gad for her preparation of the manuscript, and Drs. David N. Orth and Benjamin J. Danzo for their many helpful discussions of this work.

These studies were supported in part by a grant from the National Institutes of Health (HD 20567) and a grant for the development of young research faculty from the Andrew W. Mellon Foundation.

\section{References}

1. Griffin, J. E., and J. D. Wilson. 1980. The syndromes of androgen resistance. $N$. Engl. J. Med. 302:198-209.

2. Brown, T. R., and C. J. Migeon. 1986. Androgen receptors in normal and abnormal male sexual differentiation. In Steroid Hormone Resistance. G. P. Chrousos, D. L. Loriaux, and M. B. Lipsett, editors. Plenum Publishing. 227-255.

3. Kovacs, W. J., J. E. Griffin, and J. D. Wilson. 1986. Androgen resistance in man. In Steroid Hormone Resistance. G. P. Chrousos, D. L. Loriaux, and M. B. Lipsett, editors. Plenum Publishing, New York. 257-267.

4. Griffin, J. E. 1979. Testicular feminization associated with a thermolabile androgen receptor in cultured human fibroblasts. J. Clin Invest. 64:1624-1631.
5. Griffin, J. E., and J. L. Durrant. 1982. Qualitative receptor defects in families with androgen resistance: failure of stabilization of the fibroblast cytosol androgen receptor. J. Clin. Endocrinol. Metab. 55:465-474.

6. Brown, T. R., M. Maes, S. W. Rothwell, and C. J. Migeon. 1982. Human complete androgen insensitivity with normal dihydrotestosterone-receptor binding capacity in cultured genital skin fibroblasts: evidence for a qualitative abnormality of the receptor. J. Clin. Endocrinol. Metab. 55:61-69.

7. Chang, C. H., D. R. Rowley, T. J. Lobl, and D. J. Tindall. 1982. Purification and characterization of androgen receptor from steer seminal vesicle. Biochemistry. 21:4102-4109.

8. Chang, C. H., D. R. Rowley, and D. J. Tindall. 1983. Purification and characterization of the androgen receptor from rat ventral prostate. Biochemistry. 22:6170-6175.

9. Mainwaring, W. I. P., and V. A. Randall. 1984. Limitations in the use of tritiated methyltrienolone for the photoaffinity labelling of androgen receptor proteins. J. Steroid Biochem. 21:209-216.

10. Brinkmann, A. O., G. G. J. M. Kuiper, W. de Boer, E. Mulder, and H. J. van der Molen. 1985. Photoaffinity labelling of androgen receptors with $17 \beta$-hydroxy-17 $\alpha-\left[{ }^{3} \mathrm{H}\right]$ methyl-4,9,11-estratrien-3-one. Biochem. Biophys. Res. Commun. 126:163-169.

11. Brinkmann, A. O., G. G. J. M. Kuiper, W. de Boer, E. Mulder, J. Bolt, G. J. van Steenbrugge, and H. J. van der Molen. 1986. Characterization of androgen receptors after photoaffinity labelling with $\left[{ }^{3} \mathrm{H}\right]$ methyltrienolone (R1881). J. Steroid Biochem. 24:245-249.

12. Gyorki, S., R. James, G. L. Warne, and J. W. Funder. 1986. Photoaffinity labelling of androgen receptors from human foreskin and cultured genital fibroblasts with tritiated methyltrienolone $\left(\left[{ }^{3} \mathrm{H}\right] 1881\right)$. J. Steroid Biochem. 25:355-358.

13. Chang, C. H., T. J. Lobl, D. R. Rowley, and D. J. Tindall. 1984. Affinity labeling of the androgen receptor in rat prostate cytosol with 17 $\beta$-[(bromoacetyl)oxyl-5 $\alpha$-androstan3-one. Biochemistry. 23:25272533.

14. Rowley, D. R., C. H. Chang, and D. J. Tindall. 1984. Effects of sodium molybdate on the androgen receptor from the $\mathrm{R} 3327$ prostatic tumor. Endocrinology. 114:1776-1782.

15. Le Gaillard, F., and M. Dautrevaux. 1977. Affinity labelling of human transcortin. Biochim. Biophys. Acta. 495:312-323.

16. Mainwaring, W. I. P., and A. D. Johnson. 1980. Use of the affinity label $17 \beta$ bromoacetoxy testosterone in the purification of androgen receptor proteins. In Perspectives in Steroid Receptor Research. F. Bresciani, edited. Raven Press, New York. 88-97.

17. Griffin, J. E., K. Punyashthiti, and J. D. Wilson. Dihydrotestosterone binding by cultured human fibroblasts. J. Clin. Invest. 57:1342-1351.

18. Lowry, O. H., N. J. Rosebrough, A. L. Farr, and R. J. Randall. 1951. Protein measurement with the Folin phenol reagent. J. Biol. Chem. 193:265-275.

19. Kovacs, W. J., J. E. Griffin, D. D. Weaver, B. R. Carlson, and J. D. Wilson. 1984. A mutation that causes lability of the androgen receptor under conditions that normally promote transformation to the DNA-binding state. J. Clin. Invest. 73:1095-1104.

20. Laemmli, U. K. 1970. Cleavage of structural proteins during the assembly of the head of bacteriophage $\mathrm{T}_{4}$. Nature (Lond.). 227:680-685.

21. Dure, L. S., W. T. Schrader, and B. W. O'Malley. 1980. Covalent attachment of a progestational steroid to chick oviduct progesterone receptor by photoaffinity labelling. Nature (Lond.). 283:784-786.

22. Birnbaumer, M., W. T. Schrader, and B. W. O'Malley. 1983. Photoaffinity labeling of the chick progesterone receptor proteins. $J$. Biol. Chem. 255:1637-1644.

23. Nordeen, S. K., N. C. Lan, M. O. Showers, and J. D. Baxter. 1981. Photoaffinity labeling of glucocorticoid receptors. J. Biol. Chem. 256:10503-10508.

24. Katzenellenbogen, J. A., K. E. Carlson, D. F. Heiman, D. W. Robertson, L. L. Wei, and B. S. Katzenellenbogen. 1983. Efficient and 
highly selective covalent labeling of the estrogen receptor with [3H]tamoxifen aziridine. J. Biol. Chem. 258:3487-3495.

25. Eisen, H. J., F. E. Schleenbaker, and S. S. Simons, Jr. 1981. Affinity labeling of the rat liver glucocorticoid receptor with dexamethasone 21-mesylate. J. Biol. Chem. 256:12920-12925.

26. Taylor, C. A., Jr., H. E. Smith, and B. J. Danzo. 1980. Photoaffinity labeling of rat androgen binding protein. Proc. Natl. Acad. Sci. USA. 77:234-238.

27. Taylor, C. A., H. E. Smith, and B. J. Danzo. 1980. Characterization of androgen-binding protein in rat epididymal cytosol using a photoaffinity ligand. J. Biol. Chem. 255:7769-7773.

28. Risbridger, G. P., B. A. K. Khalid, G. L. Warne, and J. W. Funder. 1982. Differences in proteins synthesized by fibroblasts from normal individual and patients with complete testicular feminization. J. Clin. Invest. 69:99-103.

29. Rosenmann, E., C. Kreis, R. G. Thompson, M. Dobbs, J. L. Hamerton, and K. Wrogemann. 1982. Analysis of fibroblast proteins from patients with Duchenne muscular dystrophy by two-dimensional gel electrophoresis. Nature (Lond.). 298:563-566.

30. Thompson, R. G., B. Nickel, S. Finlayson, R. Meuser, J. L. Hamerton, and K. Wrogemann. 1983. 56K fibroblast protein not specific for Duchenne muscular dystrophy but for skin biopsy site. Nature (Lond.). 304:741-742.

31. Wrogemann, K., E. Kaufman, and L. Pinsky. 1987. A 56K protein is related to the human androgen receptor. UCLA Symposium on Molecular Biology, Steroid Hormone Action 113(B130) (Abstr.) 